\title{
Paleomagnetism of seamounts in the West Philippine Sea as inferred from correlation analysis of magnetic anomalies
}

\author{
Yoshio Ueda \\ Japan Coast Guard Academy, 5-1 Wakaba-cho, Kure-si, Hiroshima 737-0832, Japan \\ (Received February 13, 2004; Revised August 31, 2004; Accepted September 4, 2004)
}

\begin{abstract}
Magnetization vectors of seamounts and edifices in the West Philippine Sea were determined with a direct searching method in the space domain using the topography and magnetic anomaly data at the sea surface. The data analyzed were surveyed by the Hydrographic and Oceanographic Department of Japan since the 1980s. Several seamounts in the eastern part of the Minami Daito Basin are magnetized in the $\mathrm{N} 70^{\circ} \mathrm{W}$ to $\mathrm{N} 80^{\circ} \mathrm{W}$ directions with negative shallow inclinations, whereas edifices of the Kyushu-Palau Ridge have directions of $\mathrm{N} 30^{\circ} \mathrm{W}$ with downward inclinations. The paleolatitude of the Oki-Daito Ridge as a whole is $4.4^{\circ} \mathrm{S} \pm 11.0^{\circ}$ and that of the Amami Plateau and the Daito Ridge, $15.1^{\circ} \mathrm{N} \pm 4.6^{\circ}$ and $20.1^{\circ} \mathrm{S} \pm 8.2^{\circ}$, respectively. These results are inconsistent with the proposed clockwise rotation of the West Philippine Sea exceeding $80^{\circ}$. Furthermore, the results also suggest that the Oki Daito Ridge was generated in the Southern Hemisphere and then migrated northward. The large shortening between the Oki-Daito Ridge and the Amami-Daito Ridge regions may suggest the convergence boundary between them.
\end{abstract}

Key words: Seamount, Philippine Sea, paleomagnetism, magnetic anomalies.

\section{Introduction}

The magnetic field over oceanic seamounts often shows dipole-type magnetic anomalies. Combining magnetic field anomalies with seamount topographic data, we can derive a mean magnetization vector producing magnetic anomalies by inversion techniques. A seamount's magnetization provides useful information not only about the paleomagnetic field, but also about the tectonic movement which affected the seamount's magnetization. Sea-bottom surveys during the last several decades show the existence of many topographic edifices in the West Philippine Sea. However, only a few studies have addressed seamount magnetism (Vacquier and Uyeda, 1967; Ueda et al., 1990). As to the origin of the West Philippine Sea, two conflicting frameworks have been proposed. Uyeda and Ben-Avraham (1972) postulated that the West Philippine Sea was a part of the Kula plate trapped as a marginal sea by the change of the Pacific plate motion at $43 \mathrm{Ma}$. Their original model was then further revised for the longitudinal location of the subduction at 43 Ma (Matsuda, 1978; Uyeda and McCabe, 1983). On the other hand, a the back-arc spreading origin has also been proposed (Karig, 1975; Klein and Kobayashi, 1980; Seno and Maruyama, 1984). These models assume the rotation of the whole Philippine Sea in a conflicting manner. The former framework combined with a slab-anchored model postulates that the proto-Izu-Ogasawara trench was located in nearly its present geographical arrangement and that the back-arc basin was produced behind the arc, resulting in counter-clockwise rotation of the West Philippine Sea. The latter framework

Copy right (c) The Society of Geomagnetism and Earth, Planetary and Space Sciences (SGEPSS); The Seismological Society of Japan; The Volcanological Society of Japan; The Geodetic Society of Japan; The Japanese Society for Planetary Sciences; TERRAPUB. explains the origin of the Philippine Sea by assuming that the trench has been retreating seaward during the back-arc spreading process, which has resulted in clockwise rotation of the whole Philippine Sea by as much as $90^{\circ}$.

The succeeding researches into the origin of the West Philippine Basin incorporated detailed topographic characteristics and paleomagnetic measurements of islands samples in the marginal area of the Philippine Sea. These studies suggested that the proto-Kyushu-Palau Ridge was arranged in a nearly E-W direction and then rotated clockwise with the back arc spreading at the Central Basin Fault before $55 \mathrm{Ma}$ (Haston and Fuller, 1991; Koyama et al., 1992; Hall et al., 1995; Deschamps and Lallemand, 2002; Hall, 2002). However, the origin and development of the northern part of the West Philippine Basin, characterized by the Amami-Daito Ridge provinces including Oki-Daito Ridge, is not convincingly explained.

Although seamount paleomagnetism gives a crude measure of the paleomagnetic direction, two opposite rotations of such magnitude should be easily distinguished. This paper presents paleomagnetic information of the edifices in the Philippine Sea, which are estimated by a direct searching method for derivation of a magnetization vector from magnetic and topographic data.

\section{Data}

Figure 1 shows a topographic map of part of the Philippine Sea with the numbers indicating the edifices analyzed. The data sources are based on surveys around Japan carried out by the HOD (Hydrographic and Oceanographic Department of Japan; previously the Hydrographic Department of Japan). The $2^{\prime} \times 2^{\prime}$ mesh topographic data supplied from the General Bathymetric Chart of the Oceans (GEBCO) data 

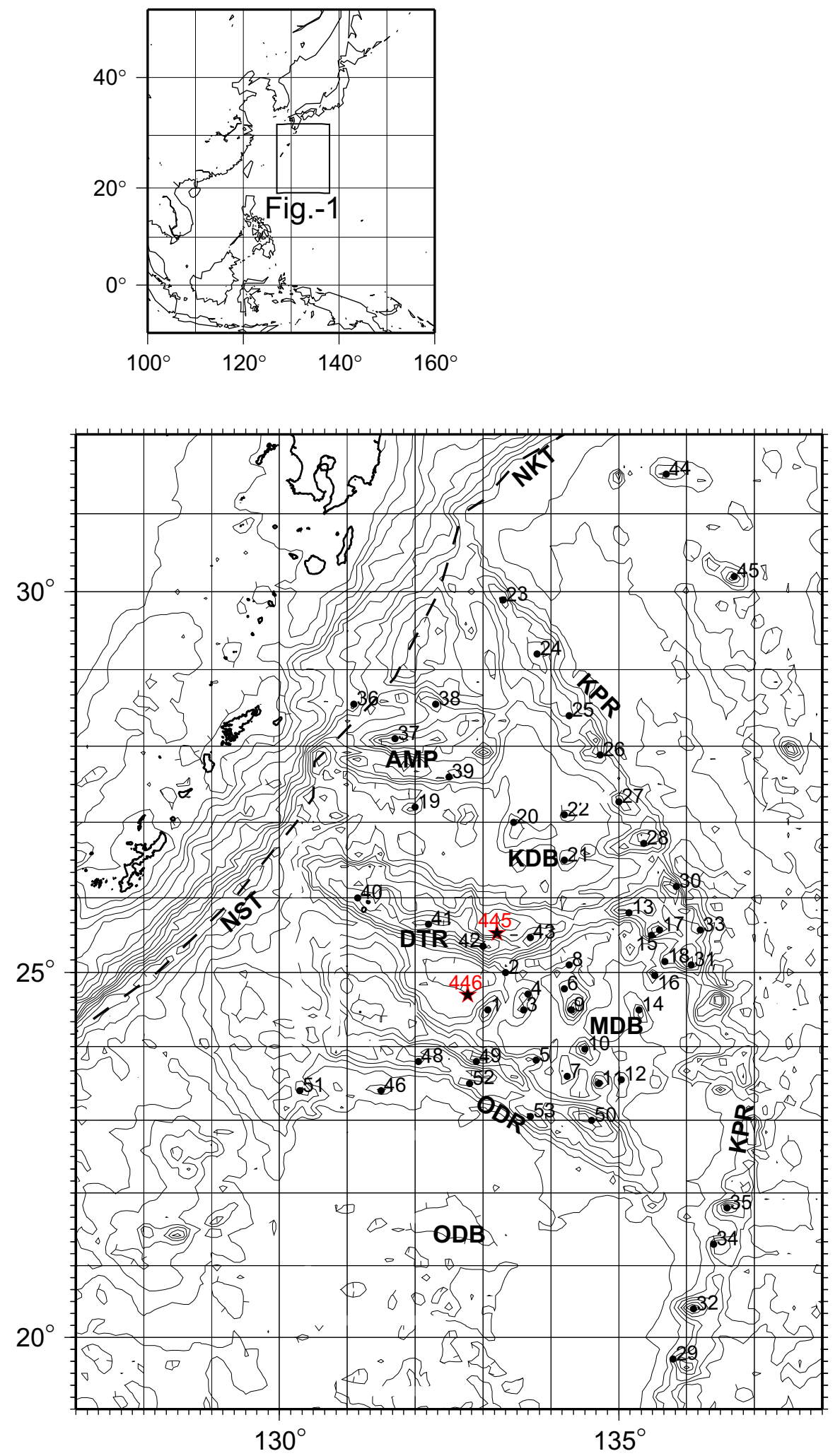

Fig. 1. Bathymetry and location map of seamounts and edifices analyzed. Contour interval is $500 \mathrm{~m}$. Broken lines indicate the trench axes of the Nansei-syoto Trench (NST) and Nankai Trough (NKT). Star marks of 445 and 446 mean the DSDP sites. AMP: Amami Plateau, DTR: Daito Ridge, ODR: Oki Daito Ridge, KPR: Kyusyu Palau Ridge, KDB: Kita Daito Basin, MDB: Minami Daito Basin, ODB: Oki Daito Basin.

were also used for the area when the above survey data were not available. Magnetic anomaly data were also mainly surveyed by the HOD and augmented by the data in the Marine Geophysical Data Exchange Format in 1977 (MGD77) supplied by the Japanese Oceanic Data Center (JODC) and the
National Geophysical Data Center of the U.S.A. (NGDC). The external field corrections were carried out by using such land magnetic stations as the Hatijyo hydrographic observatory (Japan Coast Guard) and the Kanoya and Titijima observatories (Meteorological Agency). Magnetic anomalies 


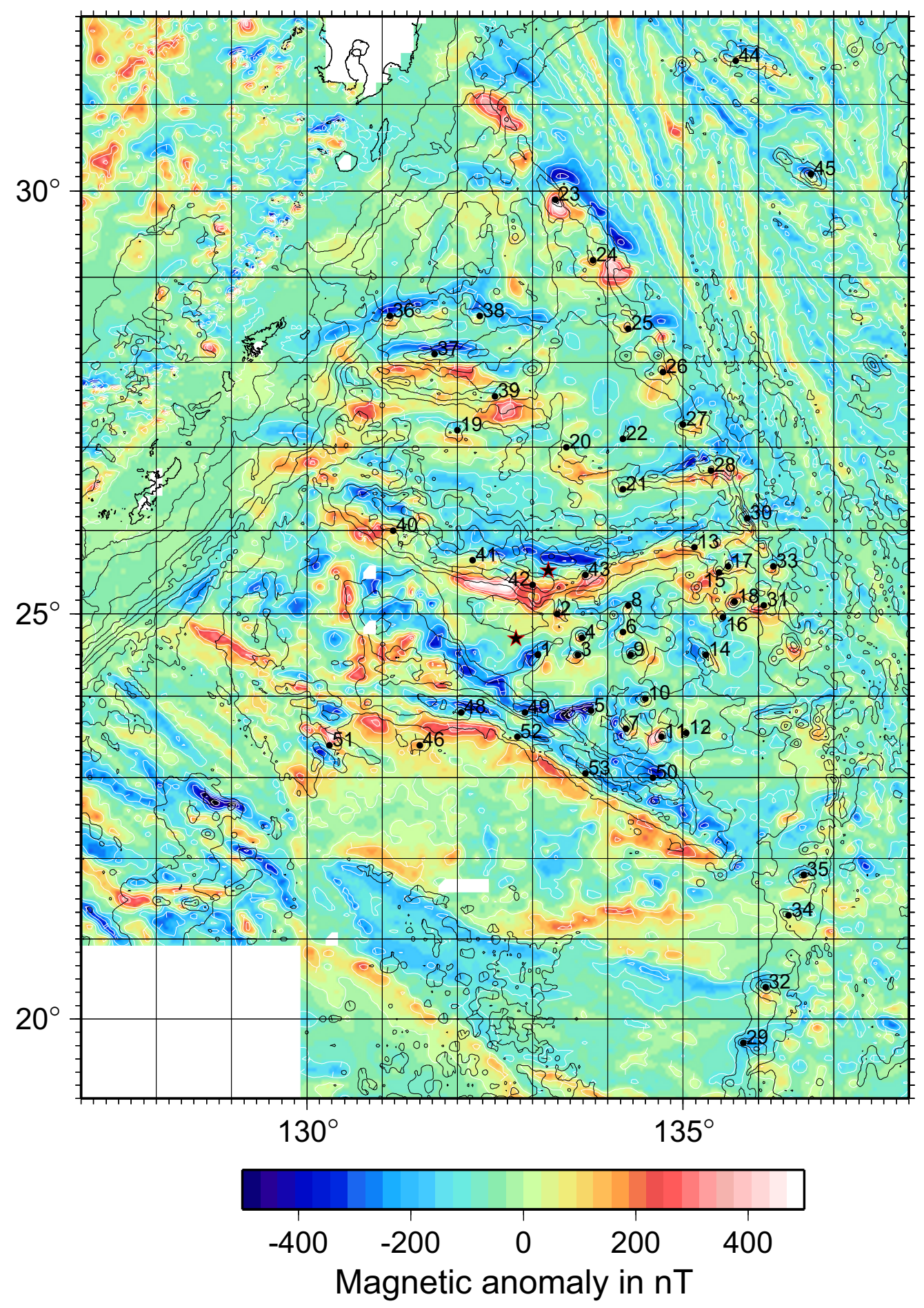

Fig. 2. Magnetic anomalies of total force in the West Philippine Sea. Contour interval of magnetic anomaly is $100 \mathrm{nT}$.

were calculated by subtracting the IGRF (International Geomagnetic Reference Field) 7th generation model from the observed ones. The sampled data were mapped by GMT (3.4 version) (Wessel and Smith, 1991) and then any erroneous data were subtracted. The refined topographic and magnetic data were then compiled as $2.5 \times 2.5 \mathrm{~km}$ mesh data files using a GMT algorithm. Topographic and magnetic anomaly data covering the target area were extracted from mother files and then analyzed by using the method described in the next section. Figure 2 shows the colored magnetic anomalies map superimposed on the topographic contours. This figure shows that the magnetic lineations peculiar to the oceanic plate are obscured or are hard to recognize in both the Minami Daito Basin (MDB) and in the Kita Daito Basin (KDB). Instead, they are characterized by the dipole-magnetic anomalies caused by seamounts. The Daito Ridge shows large magnetic anomalies with an amplitude of $\sim 800 \mathrm{nT}$ in the extreme case. The Amami Plateau and the Oki-Daito Ridge also show remarkable anomalies of $\sim 500$ to $\sim 700 \mathrm{nT}$, corresponding the topographic edifices. These features may imply that the basaltic to andesitic rocks having a relatively large magnetization intensity, partly consist of the 


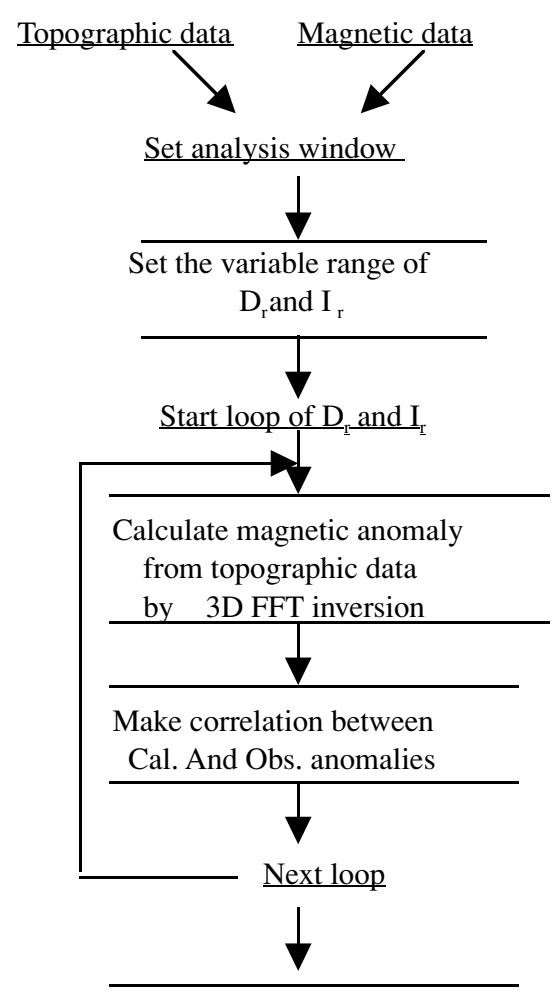

Find Dr and Ir giving maximum fitting parameter

Fig. 3. Flow chart of a correlation analysis of magnetic anomalies for determination of a magnetization direction.

uplifts of these geological provinces. Magnetic lineations in the southern part of Fig. 2 are those produced by the spreading at the Central Basin Fault (Mrozowski et al., 1982; Hilde and Lee, 1984). The topographic and magnetic charts including the major part of the present study were compiled and published by the HOD (Kasuga et al., 1994).

\section{Method}

Vacquier (1962) developed a method to obtain the mean magnetization of a seamount by a least square inversion technique using observed magnetic anomalies and a topographic model of a seamount. This method were further developed and applied for many seamounts (Talwani, 1965; Harrison et al., 1975; Plouff, 1976; McNutt, 1986). The model, assuming that the seamount has a uniform magnetization throughout the body, often causes a considerable miss-fit between the observed and calculated anomalies. To assess these results, a goodness-of-fit ratio (Uyeda and Richards, 1966) is widely used. Thereafter, Parker (1988) developed a linear inverse theory in Hilbert space to calculate a magnetization model by maximizing the uniform part (usually called the semi-norm method), and applied to Pacific seamounts (Hildebrand and Parker, 1987). This method is usuful for analysis of a non-uniformly magnetized seamount. However, no distinguishable differences between the usual method and the semi-norm method are recognizable in practice when the results have a goodness-of-fit ratio (GFR: the ratio of the mean absolute observed anomalies against the mean absolute residuals as defined in Eq. (3)) greater than 2.0 as noticed by
Sager and Pringle (1988).

The present method uses the direct searching algorithm led by such precision parameters as standard deviations, GFR, and correlation coefficients, instead of the usual leastsquare method. A general concept of the present method is explained as follows with the flow chart illustrated in Fig. 3.

When the topographic mesh data are given, the magnetic anomalies caused by the topographic model can be calculated by Eq. (1).

$$
\begin{gathered}
F(u, v)=2 \pi J \cdot \frac{1}{w} \cdot(l u+m v-i n w) \cdot(L u+M v-i N w) \\
\cdot \exp (-w D) \cdot \sum_{n=1} \frac{w^{n-1}}{n !} \cdot H_{n}(u, v)
\end{gathered}
$$

where, $z=0$ is the observed plane, and the topographic mean depth is $D$. The positive $z$ axis is vertical down and those of $x$ and $y$ mean geographically northward and eastward, respectively. The topographic relief relative to the mean depth $h(x, y)$ is measured upward, $H(u, v)$ denotes the Fourier transform of the $n$th degree of a relief given by $h^{n}(x, y)$, and $F(u, v)$ is that of the magnetic anomaly, $u, v$ are the wavenumbers in $x$ and $y$ directions, and $w$ is $\left(u^{2}+v^{2}\right)^{1 / 2}, l, m, n$ are direction cosines of the present magnetic field, and $L, M, N$ are those of the magnetization vector, $J$ is magnetization intensity, $i$ is a unit imaginary number, respectively. This equation can be derived by expanding Parker's (1973) equation to the 3D case, as given by Richard (1995).

The calculated magnetic anomalies (Cal) depend on the magnetization direction defined by the inclination $\left(I_{r}\right)$ and declination $\left(D_{r}\right)$ angles as well as the external magnetic field direction. By changing the assumed values of $D_{r}$ and $I_{r}$, which are programmed to change within the pre-assumed zones every one-degree interval, several precision parameters, such as standard deviation values $(\sigma)$, and goodnessof-fit-ratios (GFR), correlation coefficients (Cor: Grauch, 1987), are calculated using the following equations:

$$
\sigma=\sum_{i=1}^{N X} \sum_{j=1}^{N Y}\left(\mathrm{Obs}_{i, j}-\mathrm{Cal}_{i, j}\right)^{2} / N
$$

where $N=N X \cdot N Y$.

$$
\begin{gathered}
\mathrm{GFR}=\sum_{i=1}^{N X} \sum_{j=}^{N Y}\left|\mathrm{Obs}_{i, j}\right| / \sum_{i=1}^{N X} \sum_{j=1}^{N Y}\left|\mathrm{Obs}_{i, j}-\mathrm{Cal}_{i, j}\right| \\
\mathrm{Cor}=\sum_{i=1}^{N X} \sum_{j=1}^{N Y} \mathrm{Obs}_{i, j} \cdot \mathrm{Cal}_{i, j} /\left[\sum_{i=1}^{N X} \sum_{j=}^{N Y} \mathrm{Cal}_{i, j}^{2} \cdot \mathrm{Obs}_{i, j}^{2}\right]^{\frac{1}{2}},
\end{gathered}
$$

where, $\mathrm{Cal}_{i, j}$ and $\mathrm{Obs}_{i, j}$ are calculated and observed magnetic anomalies at the grid of $(i, j) . N X$ and $N Y$ are the window size of the target area.

By mapping the values of precision parameters in twodimensional coordinates defined by the inclination ( $Y$-axis) and the declination ( $X$-axis), the best fitting parameters of $D_{r}$ and $I_{r}$ can be estimated from the point giving the maximum precision parameters (the minimum point corresponds in the 


\section{Standard deviation}

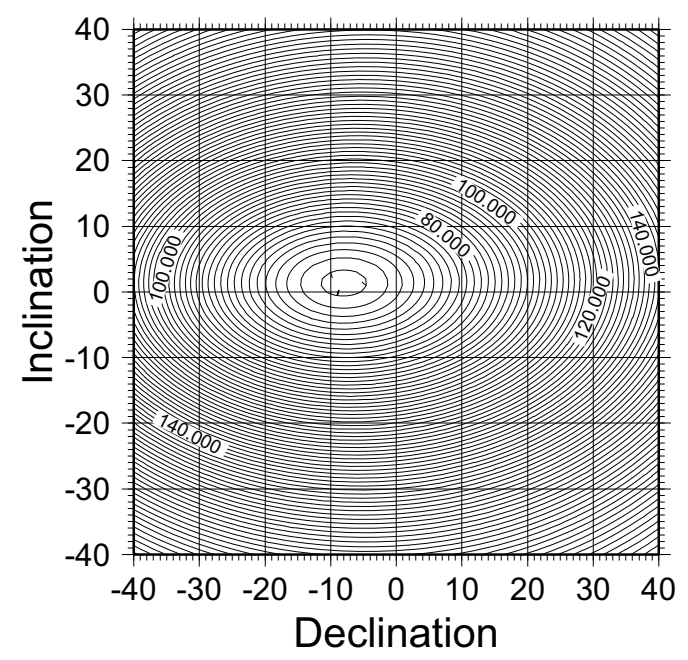

\section{GFR}

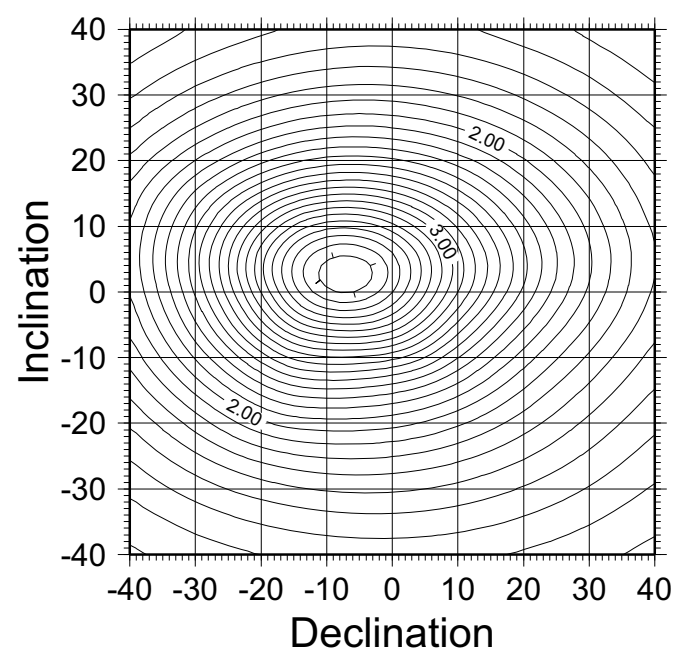

Fig. 4. Standard deviations and goodness-of-fit ratios due to the change of assumed declination and inclination angles of magnetization.

case of $\sigma)$. The magnetization intensity $\left(J_{r}\right)$ can then be estimated by

$$
J_{r}=\sum_{i=1}^{N X} \sum_{j=1}^{N Y} \mathrm{Obs}_{i, j} \cdot \mathrm{Cal}_{i, j} / \sum_{i=1}^{N X} \sum_{j=1}^{N Y} \mathrm{Cal}_{i, j}^{2} \cdot J_{0}
$$

where, $J_{0}$ is an assumed magnetization intensity (Grauch, 1987). The present method is especially useful for rapid estimation of the magnetization of an edifice in accordance with the arbitrarily defined reliable criteria without making polygons for a topographic model.

A result whose GFR is greater than 2.0 is usually adopted for paleomagnetic considerations (Sager, 1987). In the present study, a result showing a correlation coefficient larger than 0.7 is also adopted for further discussions. From the definition of GFR, the value of 1.0 means the amplitude of observed anomalies is nearly equal to those of the residuals. This shows no improvement for an approximation by calculated anomalies, which may insist that the weight of this result should be zero. In the opposite case of the perfect approximation (GFR is infinity), we define that the weight should be 1.0. So, in calculation of a statistical mean, the weight $(w)$ defined by the following equation is used:

$$
w=(1.0-1 / \mathrm{GFR})^{n},
$$

where $n$ is an integer. In the present case, $n=2.0$ is adopted.

The present method was applied to Makarov Seamounts $\left(29.5^{\circ} \mathrm{N}, 153.5^{\circ} \mathrm{E}\right)$ in the western Pacific, which had been widely analyzed by many researchers using various methods (Harrison et al., 1975; Sager and Pringle, 1988; Hildebrand and Parker, 1987). Figure 4 shows the maps of standard deviations and goodness-of-fit ratios (GFR) in the axes of declination and inclination of the magnetization vector. The most reliable magnetization parameters, giving the least value of the standard deviation, are summarized in Table 1. The results derived by the present method agree quite well with those analyzed by a least-square and semi-norm
Table 1. Comparison of the present method with those obtained by the Talwani and semi-norm method for the Makarov Seamount.

\begin{tabular}{rcclc}
\hline \multicolumn{1}{c}{ Dr } & Ir & J (A/m) & GFR & Reference \\
\hline 352.0 & 1.0 & 8.05 & 3.76 & $* 1$ \\
355.6 & 2.4 & 8.40 & 3.1 & $* 2$ \\
1.0 & 6.4 & 8.4 & 3.4 & $* 2$ \\
352.5 & -1.5 & 8.8 & 16.6 & $* 3$ \\
\hline
\end{tabular}

*1: Present method.

*2: Talwani's method; Harrison et al. (1975), Vacquier and Uyeda (1967). *3: Semi-norm method; Hildebrand and Parker (1987).

method. This is also corroborated by sharp peaks of the criteria shown in Fig. 4. This feature indicates that the present method is valid for estimating the magnetization vector of a three-dimensional edifice, as shown by a high COR (0.968) and GFR (3.76) values.

\section{Results and Discussion}

(1) Mean Virtual Geomagnetic Pole (VGP) for the seamounts in the MDB and KPR

The present method was applied to 53 seamounts in the Philippine Sea and the calculated magnetization vectors and paleomagnetic pole positions are summarized in Table 2. The calculated VGP positions are shown in Fig. 5 for the seamounts in the Minami Daito Basin (a) and the KyusyuPalau Ridge (b), respectively.

The calculated seamount magnetizations have inherent ambiguities for their origin, because the rocks have rarely been sampled from seamounts. In the present case, the rock magnetism of the seamounts analyzed are not available. The contribution of the secondary magnetization, which was acquired after the formation of seamounts, has also been a longstanding problem for the interpretation of seamount magnetism. However, it is widely accepted that the secondary magnetization makes only a minor contribution to the total magnetization in comparison with the thermal one 
Table 2. Magnetizations and paleomagnetic poles of seamounts and edifices calculated in this study.

\begin{tabular}{|c|c|c|c|c|c|c|c|c|c|c|c|c|c|}
\hline \multirow[t]{2}{*}{ ID } & \multirow[t]{2}{*}{ GP } & \multicolumn{2}{|c|}{ Location } & \multicolumn{2}{|c|}{ Paleo-pole } & \multicolumn{4}{|c|}{ Magnetization } & \multicolumn{3}{|c|}{ Criteria } & \multirow[t]{2}{*}{ Smt Name } \\
\hline & & Lon & Lat & Lon & Lat & $\mathbf{J}^{* 1}$ & $\mathrm{Dr}$ & $\mathrm{Ir}$ & $\mathrm{Lat}^{* 2}$ & corr. & GFR & $\sigma$ & \\
\hline 1 & 1 & 133.07 & 24.50 & 28.8 & 13.2 & 5.43 & 288.0 & -14.0 & -7.1 & 0.853 & 2.03 & 67.5 & Kanreki \\
\hline 2 & 1 & 133.33 & 25.00 & 305.0 & 76.3 & 5.07 & 2.0 & 22.0 & 11.4 & 0.891 & 2.22 & 39.9 & \\
\hline 3 & 1 & 133.60 & 24.50 & 323.0 & 77.9 & 4.11 & 358.0 & 24.0 & 12.6 & 0.884 & 2.33 & 41.9 & Koki \\
\hline 4 & 1 & 133.66 & 24.71 & 263.0 & 62.6 & 1.77 & 21.0 & 12.0 & 6.1 & 0.808 & 1.68 & 37.6 & Kizyu \\
\hline 5 & 1 & 133.78 & 23.82 & 26.8 & 13.0 & 7.61 & 289.0 & -19.0 & -9.8 & 0.933 & 2.95 & 50.9 & Mutuki \\
\hline 6 & 1 & 134.20 & 24.78 & 64.5 & 27.3 & 6.00 & 289.0 & 47.0 & 28.2 & 0.969 & 4.46 & 21.8 & \\
\hline 7 & 1 & 134.24 & 23.60 & 50.1 & 5.8 & 4.32 & 273.0 & 15.0 & 7.6 & 0.764 & 1.59 & 82.5 & Kisaragi \\
\hline 8 & 1 & 134.27 & 25.10 & 81.8 & -23.0 & 3.90 & 231.0 & 36.0 & 20.0 & 0.925 & 2.85 & 27.2 & \\
\hline 9 & 1 & 134.30 & 24.50 & 33.4 & 22.6 & 2.24 & 295.0 & 0.0 & 0.0 & 0.636 & 1.29 & 57.4 & Beizyu \\
\hline 10 & 1 & 134.50 & 23.97 & 44.3 & 23.8 & 4.48 & 292.0 & 18.0 & 9.2 & 0.918 & 2.40 & 30.8 & Yayoi \\
\hline 11 & 1 & 134.71 & 23.50 & 213.9 & -11.6 & 8.85 & 105.0 & 10.0 & 5.0 & 0.907 & 2.27 & 69.6 & Satuki \\
\hline 12 & 1 & 135.04 & 23.55 & 210.5 & -4.4 & 4.75 & 100.0 & 22.0 & 11.4 & 0.841 & 1.81 & 28.7 & Minazuki \\
\hline 13 & 1 & 135.15 & 25.80 & 217.6 & 59.5 & 3.27 & 34.0 & 44.0 & 25.8 & 0.857 & 2.07 & 69.9 & \\
\hline 14 & 1 & 135.30 & 24.50 & 31.0 & 18.8 & 5.82 & 293.0 & -9.0 & -4.5 & 0.761 & 1.44 & 59.3 & Huro \\
\hline 15 & 1 & 135.48 & 25.50 & 226.2 & 19.5 & 3.63 & 72.0 & 15.0 & 7.6 & 0.883 & 2.46 & 49.4 & \\
\hline 16 & 1 & 135.53 & 24.96 & 210.2 & -42.1 & 4.38 & 134.0 & -12.0 & -6.1 & 0.953 & 3.13 & 24.8 & Nisi-Kosei \\
\hline 17 & 1 & 135.60 & 25.57 & 221.1 & 74.7 & 2.03 & 17.0 & 44.0 & 25.8 & 0.824 & 1.76 & 64.6 & Ryusei \\
\hline 18 & 1 & 135.68 & 25.15 & 188.2 & -41.3 & 2.01 & 143.0 & 15.0 & 7.6 & 0.823 & 1.84 & 53.2 & Kosei \\
\hline 19 & 2 & 132.00 & 27.20 & 291.2 & 63.8 & 6.48 & 9.0 & 5.0 & 2.5 & 0.857 & 2.23 & 50.2 & Tete \\
\hline 20 & 2 & 133.45 & 27.00 & 170.8 & 66.3 & 2.81 & 20.0 & 63.0 & 44.5 & 0.870 & 2.03 & 30.0 & \\
\hline 21 & 2 & 134.20 & 26.50 & 79.5 & 24.2 & 1.44 & 280.0 & 60.0 & 40.9 & 0.550 & 1.27 & 41.0 & Kotobuki \\
\hline 22 & 2 & 134.20 & 27.10 & 55.4 & 5.7 & 2.47 & 270.0 & 24.0 & 12.6 & 0.594 & 1.22 & 28.9 & Satuma \\
\hline 23 & 3 & 133.30 & 29.90 & 38.1 & 42.3 & 6.68 & 310.0 & 30.0 & 16.1 & 0.699 & 1.43 & 134.1 & Komahasi-Daini \\
\hline 24 & 3 & 133.80 & 29.20 & 57.0 & 45.0 & 2.74 & 308.0 & 48.0 & 29.0 & 0.608 & 1.27 & 56.5 & Tikuzen \\
\hline 25 & 3 & 134.27 & 28.40 & 113.2 & 51.8 & 1.87 & 332.0 & 75.0 & 61.8 & 0.868 & 2.22 & 32.0 & Bungo \\
\hline 26 & 3 & 134.73 & 27.89 & 27.4 & 28.5 & 2.45 & 303.0 & -1.0 & -0.5 & 0.730 & 1.52 & 56.6 & Higo \\
\hline 27 & 3 & 135.00 & 27.27 & 69.9 & 23.5 & 3.02 & 282.0 & 51.0 & 31.7 & 0.644 & 1.31 & 73.7 & Osumi \\
\hline 28 & 3 & 135.37 & 26.72 & 45.5 & 49.2 & 3.65 & 316.0 & 36.0 & 20.0 & 0.925 & 2.91 & 63.0 & Kita-Koho \\
\hline 29 & 3 & 135.80 & 19.70 & 21.8 & 54.6 & 1.80 & 328.0 & 6.0 & 3.0 & 0.742 & 1.53 & 127.7 & Tennosei \\
\hline 30 & 3 & 135.85 & 26.15 & 15.8 & 61.2 & 2.35 & 335.0 & 19.0 & 9.8 & 0.704 & 1.37 & 56.9 & Minami-Koho \\
\hline 31 & 3 & 136.07 & 25.10 & 229.6 & 68.7 & 2.22 & 23.0 & 39.0 & 22.0 & 0.936 & 2.99 & 29.5 & Higasi-suisei \\
\hline 32 & 3 & 136.10 & 20.40 & 35.0 & 66.3 & 2.30 & 336.0 & 27.0 & 14.3 & 0.875 & 2.02 & 36.5 & Oki-no Tori Sima \\
\hline 33 & 3 & 136.20 & 25.57 & 29.0 & 64.8 & 3.21 & 335.0 & 30.0 & 16.1 & 0.941 & 2.91 & 32.6 & \\
\hline 34 & 3 & 136.40 & 21.30 & 100.4 & 73.1 & 2.00 & 348.0 & 54.0 & 34.5 & 0.724 & 1.38 & 42.2 & Mokusei \\
\hline 35 & 3 & 136.60 & 21.80 & 34.7 & 60.2 & 2.21 & 330.0 & 25.0 & 13.1 & 0.961 & 3.73 & 25.6 & Kasei \\
\hline 36 & 4 & 131.10 & 28.55 & 338.4 & 70.4 & 6.78 & 351.0 & 21.0 & 10.9 & 0.887 & 2.34 & 81.5 & Kikai \\
\hline 37 & 4 & 131.70 & 28.10 & 295.8 & 79.5 & 3.48 & 3.0 & 33.0 & 18.0 & 0.878 & 2.18 & 79.8 & Nase \\
\hline 38 & 4 & 132.30 & 28.55 & 24.1 & 64.0 & 3.93 & 334.0 & 33.0 & 18.0 & 0.980 & 5.50 & 22.6 & Wan \\
\hline 39 & 4 & 132.50 & 27.60 & 262.7 & 56.5 & 6.07 & 25.0 & 8.0 & 4.0 & 0.750 & 1.55 & 83.0 & \\
\hline 40 & 5 & 131.15 & 26.00 & 224.2 & 31.6 & 2.84 & 60.0 & 21.0 & 10.9 & 0.533 & 1.19 & 110.8 & \\
\hline 41 & 5 & 132.20 & 25.65 & 280.6 & 72.9 & 3.98 & 9.0 & 21.0 & 10.9 & 0.731 & 1.49 & 143.8 & \\
\hline 42 & 5 & 133.00 & 25.35 & 101.4 & 86.6 & 2.94 & 358.0 & 47.0 & 28.2 & 0.605 & 1.37 & 154.2 & \\
\hline 43 & 5 & 133.70 & 25.47 & 212.7 & 61.4 & 4.41 & 32.0 & 46.0 & 27.4 & 0.730 & 1.59 & 124.4 & \\
\hline 44 & 6 & 135.70 & 31.50 & 237.4 & 56.6 & 3.16 & 35.0 & 36.0 & 20.0 & 0.838 & 1.92 & 56.1 & Kosyu \\
\hline 45 & 6 & 136.70 & 30.20 & 346.7 & 58.9 & 1.82 & 345.0 & 5.0 & 2.5 & 0.721 & 1.41 & 56.4 & Daini-Kinan \\
\hline 46 & 7 & 131.50 & 23.40 & 207.7 & -6.9 & 4.05 & 102.0 & 19.0 & 9.8 & 0.867 & 2.22 & 17.6 & \\
\hline 47 & 7 & 133.72 & 17.40 & 49.4 & 62.4 & 2.70 & 331.0 & 33.0 & 18.0 & 0.704 & 1.50 & 36.0 & \\
\hline 48 & 8 & 132.05 & 23.80 & 274.8 & 68.3 & 6.11 & 13.0 & 12.0 & 6.1 & 0.672 & 1.33 & 140.6 & \\
\hline 49 & 8 & 132.90 & 23.80 & 311.4 & 48.8 & 2.08 & 1.0 & -32.0 & -17.4 & 0.871 & 2.19 & 51.7 & \\
\hline 50 & 8 & 134.60 & 23.00 & 346.4 & 56.5 & 5.60 & 343.0 & -12.0 & -6.1 & 0.709 & 1.39 & 99.2 & \\
\hline 51 & 8 & 130.30 & 23.40 & 49.4 & -19.0 & 9.38 & 249.0 & 1.0 & 0.5 & 0.800 & 1.68 & 120.1 & \\
\hline 52 & 8 & 132.80 & 23.50 & 302.1 & 79.5 & 3.34 & 2.0 & 25.0 & 13.1 & 0.731 & 1.42 & 83.4 & \\
\hline 53 & 8 & 133.70 & 23.05 & 2.1 & 64.3 & 5.40 & 341.0 & 10.0 & 5.0 & 0.788 & 1.70 & 79.6 & \\
\hline
\end{tabular}

*1: unit in $\mathrm{A} / \mathrm{m}, * 2$ : Paleo-latitude.

ID: idetification number, GP: group number which means the location of seamounts and edifices, 1: Minami Daito Basin; 2: Kita Daito Basin; 3: Kyusyu-Palau Ridge; 4: Amami Plateau; 5: Daito Ridge; 6: Sikoku Basin; 7: Oki Daito Basin; 8: Northern part of the Oki Daito Ridge; 9: Southern part of the Oki Daito Ridge.

(Hildebrand and Staudigel, 1986; Sager, 1987). The opposite results, which indicate the significant contribution of the secondary and induced magnetizations to paleomagnetism of the oceanic rocks, are also presented (Gee et al., 1993; Gee and Nakanishi, 1995). However, in the present study, the au- thor accepts the former concept, and then points out the cases which show the contribution of secondary magnetization for individual cases.

The VGPs for the seamounts in the Minami-Daito Basin show two groups, one is relatively close to and the other is 
far apart from the present pole, reflecting westerly magnetizations. The VGP for the former group is calculated to be $254.3^{\circ} \mathrm{E}, 74.3^{\circ} \mathrm{N}$, and the $95 \%$ confidence circle $\left(\alpha_{95}\right)$ is $21.3^{\circ}$, and that of the latter group is calculated to be $36.2^{\circ} \mathrm{E}, \mathrm{N} 15.1^{\circ} \mathrm{N}$, with $\alpha_{95}$ of $15.9^{\circ}$ respectively. Sager (1987) showed that induced and viscous magnetizations in the seamount studies were insignificant. In contrary to this conclusion, the VGPs showing the normal epoch insist on the plausibility of induced or viscous magnetization. The mean intensity of magnetization for the former group $(J=3.35$ $\mathrm{A} / \mathrm{m} \pm 1.19)$ is considerably smaller than the latter group $(J=5.89 \mathrm{~A} / \mathrm{m} \pm 1.13)$. This feature may imply that the magnetization of the former group may be ascribed to the induced or viscous remanent magnetization, and the latter to the thermal remanent magnetization. However, this explanation is not conclusive and should be clarified in future by sampling rocks from seamounts. The mean VGP for the seamounts in the Kyusyu-Palau Ridge is also calculated to be $30.8^{\circ} \mathrm{E}, 59.8^{\circ} \mathrm{N}$, with $\alpha_{95}=10.6$. This result reflects a westerly deflected magnetization with a somewhat shallower inclination of magnetization.

(2) Tectonic implications of seamount paleomagnetism

The horizontal vectors of the magnetization components are shown in Fig. 6. From this figure, it is recognized that the horizontal vectors of the edifices in the Kyusyu-Palau Ridge are almost all directed about NW30 ${ }^{\circ}$ A mean magnetization direction of seamounts showing a westerly magnetization direction is $D_{r}=29.8^{\circ}, I_{r}=24.0^{\circ}, \alpha_{95}=15.3^{\circ}$. Other remarkable features are the seamounts showing a westerly deflected declination in the Minami Daito Basin (1, 5, 7, $10,14)$, as mentioned in the VGP calculations. The clockwise magnetized seamounts $(11,12)$ have reversed magnetizations just for the westerly deflected magnetized seamounts, as shown in VGP map (Fig. 5). The above-paired seamounts may be interpreted as the bodies formed during the normal and reverse polarity epochs, respectively.

The VGPs of the seamounts in the Minami Daito Basin considerably differ from the present North Pole, reflecting the westerly-deflected magnetizations. The mean magnetization directions are calculated to be $D_{r}=-73^{\circ}, I_{r}=-1.9^{\circ}$, $\alpha_{95}=25.2^{\circ}$ (smt $\left.1,5,7,10,14\right)$. Basaltic rocks at the DSDP sites 445 and 446 are determined to have ages of 59 and 57 Ma (Ozima et al., 1983), which suggests volcanic activity in the Paleocene. On the other hand, the Late Cretaceous rocks were recovered from the Amami Plateau (Matsuda et al., 1975). These age data give a lower limit of seamount activity, because K-Ar dating is affected by recent thermal alterations. The timing of seamount volcanism may be older than this dated age, although no concrete age data are available at present. Regarding this, a comparative investigation of the VGP may give the information about the age of these seamounts. The great circles connecting the dot points shown in Fig. 7 show pole locations when the declinations of the westerly-deflected magnetization vectors are rotated clockwise in steps of 10 degrees. The corrected poles intersect the mean Pacific plate polar wander path between the declination values from $340^{\circ}$ to $350^{\circ}$, where the corresponding VGP ages are $82 \sim 88 \mathrm{Ma}$ for $(1,5,14)$ and near 72 Ma for $(7,10)$, respectively. This feature suggests that the seamounts in the MDB were generated during the Late Cre-
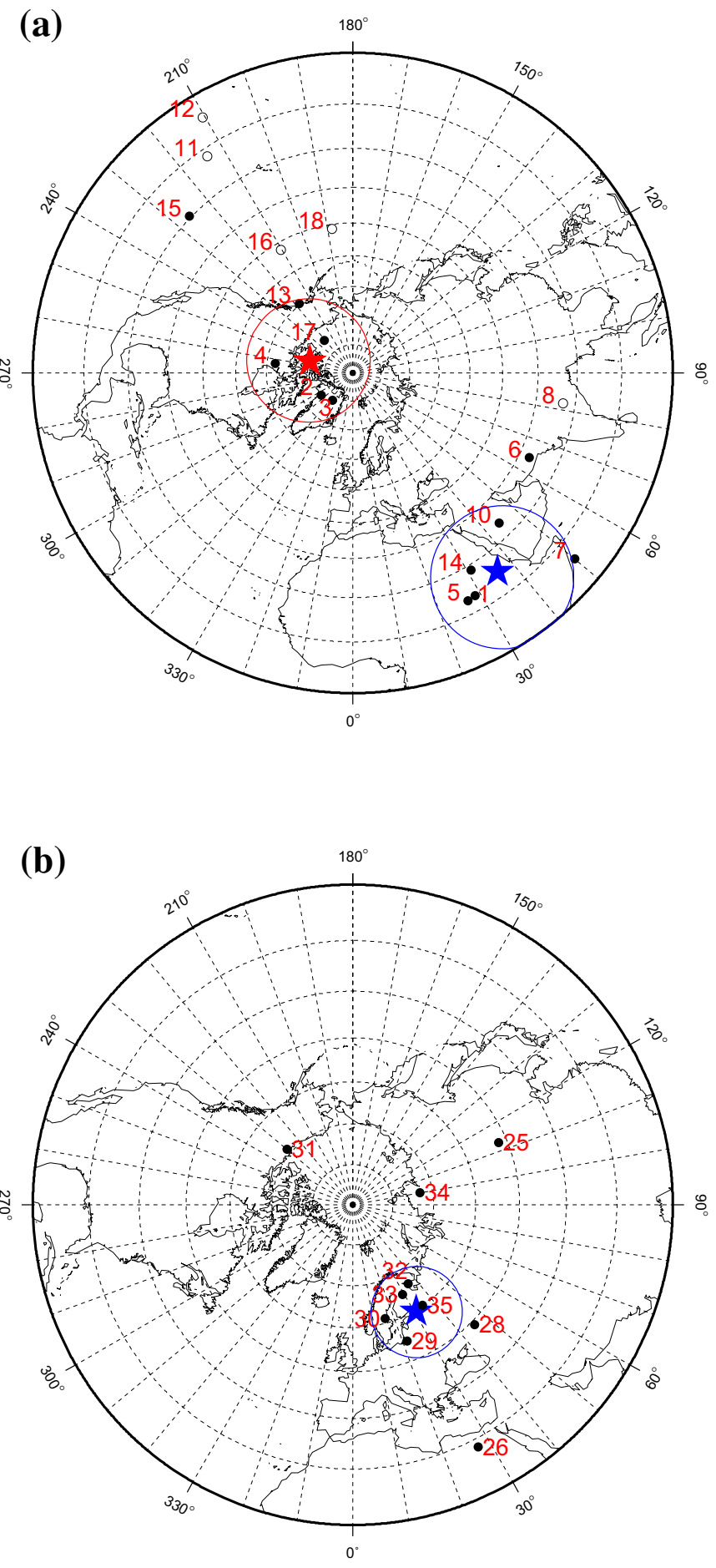

Fig. 5. VGP maps for the seamounts in the Minami Daito Basin and those in the Kytusyu-Palau Ridge. Upper: (a) Minami Daito Basin, Lower: (b) Kyusyu-Palau Ridge. Open circles $(11,12)$ mean the negative latitudes. Mean VGP s derived from seamounts in the Minami Daito Basin grouped into two groups, One $\left(-105.7^{\circ} \mathrm{E}, 74.3^{\circ} \mathrm{N}, \theta_{95}=21.3\right)$ is relatively close the the present pole and the other $\left(36.2^{\circ} \mathrm{E}, 15.1^{\circ} \mathrm{N}, \theta_{95}=15.9\right)$ is far apart from present pole reflecting the westerly deflected magnetizations. The mean VGP for the seamounts in the Kyusyu-Palau Ridge is calculated to be $30.8^{\circ} \mathrm{E}, 59.8^{\circ} \mathrm{N}, \theta_{95}=10.6$.

taceous and have undergone a relative counter-clockwise rotation amounting to $\sim 60^{\circ}$ against the Pacific plate.

Other edifices, such as the Amami Plateau and the Daito Ridge, have magnetization vectors roughly northward. This 


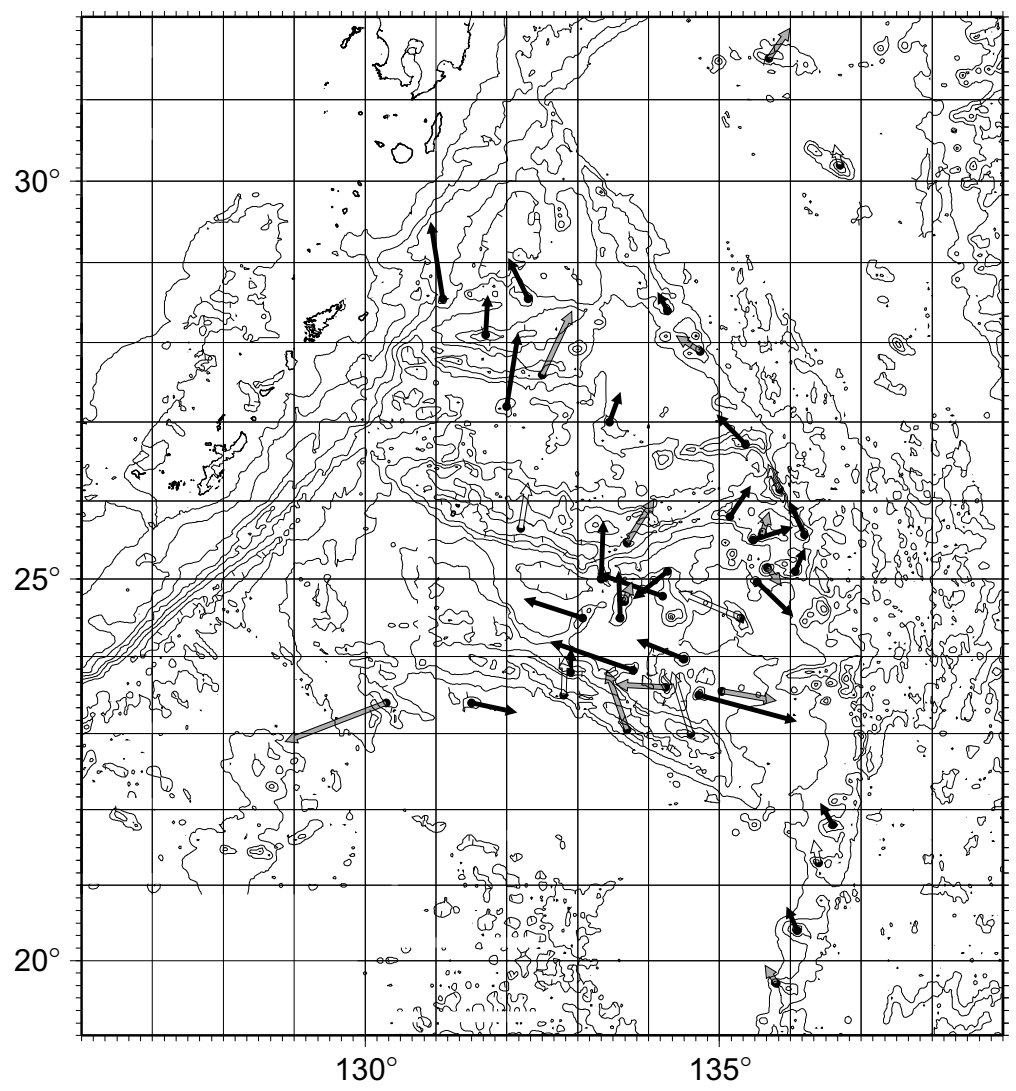

Fig. 6. Horizontal projections of magnetization vectors. Results with the correlation value larger than 0.70 are plotted. Black arrow: GFR $>2.0$, gray arrow: $1.5<\mathrm{GDR}<2.0$, white arrow: GFR $<1.5$. Length is proportional to magnetization intensity.

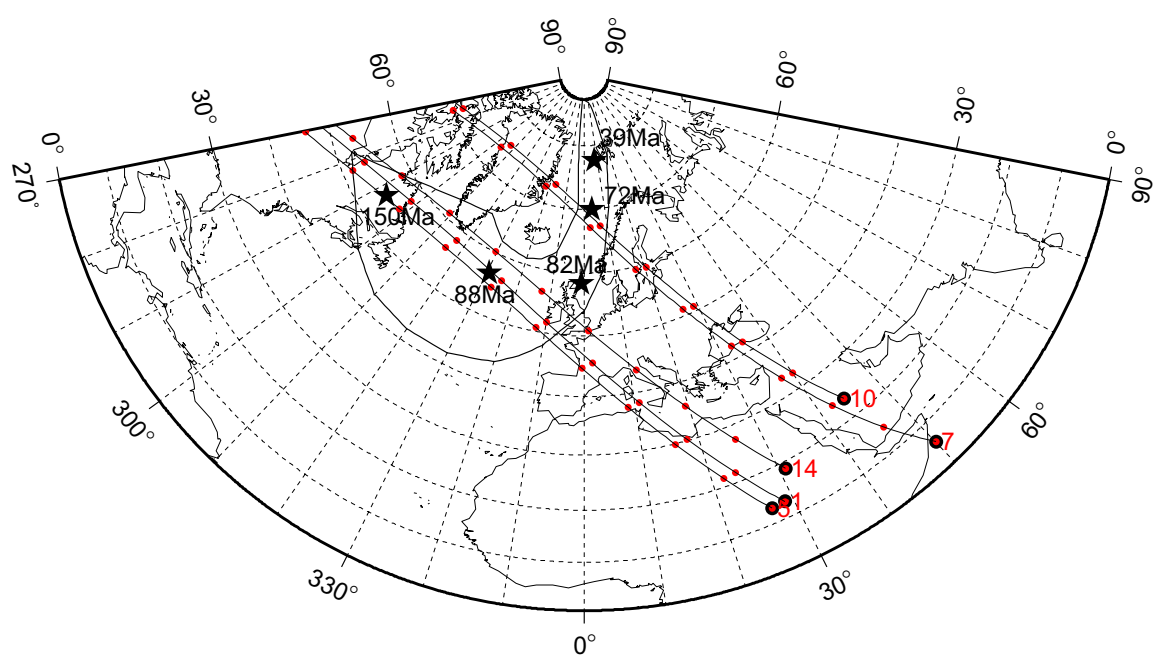

Fig. 7. Paleomagnetic poles of the seamounts in the Minami Daito Basin. The great circle connecting the dot points is a polar curve when the westerly deflected declination angle is corrected clockwisely in steps of 10 degrees. Mean paleomagnetic poles of 39, 72, 82, and 88 Ma (Sager and Pringle, 1988 ) and $150 \mathrm{Ma}$ are shown with a suggested Pacific plate polar wander curve (Hildebrand and Parker, 1987).

suggests that the counter-clockwise rotation is not ascribed to the whole rotation of the Philippine Sea, but to the local rotation restricted in the eastern part of the Minami Daito Basin. The counter-clockwise rotation of the Kyusyu-Palau Ridge is about $30^{\circ}$, which may be caused by back arc spreading of the Shikoku and Oki-no-Torisima Basin (Parece-Vela Basin). The seamounts in the Minami Daito Basin, moreover, have undergone a considerable amount of counter-clockwise ro- tation, resulting in $\sim 60^{\circ}$ in the extreme case. The origin of the latter may be explained by back arc rifting separating the Amami Plateau and the Daito Ridge, as proposed by Tokuyama et al. (1986).

Contrary to the present results, paleomagnetism of the volcanic samples on the islands and DSDP cores in the fore-arc region of the Izu-Mariana arc shows clockwise deflected declination amounting to more than $\sim 80^{\circ}$ (Haston and Fuller, 
1991; Keating and Herrero, 1980; Kodama et al., 1983; Koyama et al., 1992), while, magnetic skewness analyses suggest two conflicting results, one indicating $\mathrm{CW}$ roation about 60 during the Tertiary (Louden, 1977; Shin, 1980), and the other about $50 \mathrm{CCW}$ rotation (Bowin et al., 1978). One interpretation of the $70^{\circ} \sim 80^{\circ} \mathrm{CCW}$ vector is the reversed and anti-direction, representing a $\sim 100^{\circ}$ clockwise direction in the normal direction. In fact, the calculated $95 \%$ confidence is large (25.2) and the above interpretation cannot be excluded statistically. However, taking into account the other westerly deflected seamounts in the Kyusyu-Palau Ridge, the above interpretation seems to be inconceivable.

Hall et al. (1995) have synthesized the paleomagnetic records and suggested the rotation history of the Philippine Sea Plate since the early Eocene, taking into account the paleomagnetic data in the southern part of the Philippine Plate $\left(40^{\circ} \mathrm{CW}\right.$ rotation between 0 and $25 \mathrm{Ma}$, no significant rotation from between 25 and $40 \mathrm{Ma}, 50^{\circ} \mathrm{CW}$ rotation between 40 and $50 \mathrm{Ma}$ ). Their new data in the Lower Eocene sites have a clock-wisely deflected declination amounting $\sim 90^{\circ}$. However, as pointed out by them, the Late Cretaceous rocks in the Halmahera Island in the southern part of the Philippine Sea Plate shows a normal direction. Although they attribute this normal declination to the rotation occurring before the Early Eocene, it was not included in their model. Besides, the Oligocene declinations showing $\sim 90^{\circ}$ deflected declination, as recovered from the ODP Leg 126 core samples in the Izu-Bonin forearc region (Koyama et al., 1992), considerably differ from a deflection angle predicted by Hall $e t$ al. (1995). As mensioned above, it should be noted that the present clockwise rotational model does not fully succeed in explaining the paleomagnetic data. This origin may be ascribed to a lack of palaeomagnetic data in the northern and western Philippine Plate margins, as they pointed out.

The author does not have concrete evidence to explain the contradiction at present. However, the plausible explanation may ascribe the clockwise deflected declination observed in the fore-arc region of the Izu-Mariana island arc, to the systematic rotation caused by oblique subduction of the Pacific plate, as suggested by Kodama et al. (1983). Recent paleomagnetic studies on the continental margin of the South America actually show the occurrence of block rotations caused by oblique subduction (Randall et al., 1996; Beck, 1998) which may, on the whole, support the block rotational origin of the clockwise deflection. Another origin of the large CW deflection angle may be an episodic true polar wandering event and/or the contribution of the non-dipole component. More intimate discussions about these possibilities are outside the scope of the present paper. However, the above possibilities should be reviewed in relation to the $\mathrm{CW}$ deflection angles of the rock samples in the marginal area of the Philippine Sea.

(3) Paleolatitude of the Amami and Daito Ridge provinces

Figure 8 shows the relationship between the paleolatitudes deduced from the inclination of magnetization vectors and the geographical latitude of the edifices in the Amami plateau, Daito Ridge and Oki Daito Ridge. The mean paleolatitudes of these edifices are $15.1^{\circ} \mathrm{N} \pm 4.6^{\circ}, 20.1^{\circ} \mathrm{N} \pm 8.2^{\circ}$ and $4.4^{\circ} \mathrm{S} \pm 11.0^{\circ}$, respectively. As to the Daito Ridge, the paleolatitudes show bi-modal groups, one is around $10.9^{\circ} \mathrm{N}$

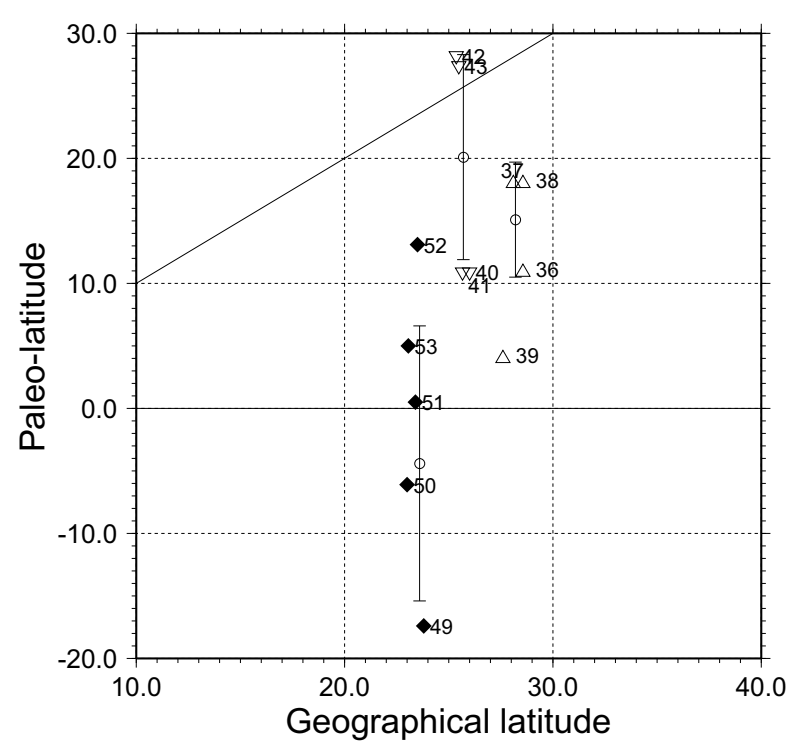

Fig. 8. Relation between the calculated paleolatitude and the geographical latitude of the seamounts located in the Amami Plateau, in the Daito Ridge, and in the Oki-Daito Ridge are plotted with the mean values and error bars of standard deviations. The mean paleolatitude of the Oki Daito Ridge is $4.4^{\circ} \mathrm{S} \pm 11.0^{\circ}$, and that of the Daito Ridge and the Amami Plateau are $20.1^{\circ} \mathrm{N} \pm 8.2^{\circ}$ and $15.1^{\circ} \mathrm{N} \pm 4.6^{\circ}$, respectively. Open triangles: Amami Plateat, Open inverted triangles: Daito Ridge. Solid diamonds: Oki Daito Ridge.

and the other near the present latitude. The former group is consistent with the paleomagnetism of DSDP core at sites 445 and 446 (Kinoshita, 1980). A magneto-gravity response analysis of the Daito-Ridge shows the magnetization inclination close to present geographic latitude (Ueda et al., 2002), which is consistent with the results of the latter group. This feature may imply that the magnetization of the Daito Ridge is partly caused by a viscous or induced magnetization instead of a remanent magnetization, although magnetic property of the rocks forming the Daito Ridge should be clarified for a final judgment on this matter. As mentioned above, some ambiguities exist about paleomagnetism of the Daito Ridge. However, it may be concluded that the Amami plateau and the Daito Ridge were generated in the Northern Hemisphere somewhat in a lower latitude than the present location. On the other hand, the Oki Daito Ridge were formed in the Southern Hemisphere near the equatorial region and then migrated to the present location.

It is should be noticed that these paleolatitudinal data were not influenced by tectonic rotations in the horizontal plane, so the shortening along the meridian still stands for the relative movement among them. The vertical rotations of these edifices were assumed to be negligible, because of no reliable data to judge the occurrence of these events are available. The present results insist on considerable shortening amounting over $1300 \mathrm{~km}$ between the Oki Daito Ridge and the Daito Ridge, as noted from the comparison of paleolatitudes. This aspect may indicate that the convergence tectonic boundary had been situated between the Oki Daito and Daito Ridges during the northward migration of the Oki Daito Ridge. The above interpretation is in accordance with a multi-channel seismic profile showing a northward subduction process south of the Daito Ridge (Honza and Fujioka, 
2004), and may also support the occurrence of back-arc rifting behind the Oki Daito Ridge, as suggested by Tokuyama et al. (1986).

\section{Conclusions}

A new method for the estimation of a magnetization vector from magnetic and topographic data was developed using correlation analysis in a space domain. This method was applied to 53 seamounts and edifices in the West Philippine Sea and the following features have become apparent:

(1) The declinations of magnetization vectors of the edifices in the Kyusyu-Palau Ridge are deflected westerly by $\sim 30^{\circ}$. (2) Several seamounts in the Minami Daito Basin are magnetized $\mathrm{N} 70^{\circ} \mathrm{W}$ to $\mathrm{N} 80^{\circ} \mathrm{W}$ with upward inclinations of about $10^{\circ}$ and two seamounts have reverse components corresponding to this magnetization vector. These features suggest that the eastern part of the Minami Daito Basin has undergone counter-clockwise rotation of as much as $80^{\circ}$.

(3) The mean paleolatitude of the Oki Daito Ridge is $4.4^{\circ} \mathrm{S} \pm 11.0^{\circ}$, and that of the Daito Ridge and the Amami Plateau are $20.1^{\circ} \mathrm{N} \pm 8.2^{\circ}$ and $15.1^{\circ} \mathrm{N} \pm 4.6^{\circ}$, respectively. This result suggests that the convergence boundary was located at the south of the Daito Ridge during the northward migration of the Oki Daito Ridge.

(4) Paleomagnetism of the seamounts and edifices of the West Phillipine Sea is not consistent with a clockwise rotational model of the whole of the Philippine Sea, which has been postulated from the paleomagnetism of volcanic rock samples and DSDP cores in the Izu-Mariana fore arc region.

Acknowledgments. The author would like to express his hearty thanks to the JODC (Japanese Oceanographic Data Center) for providing MGD77 data used in this study. He is also grateful to the staff of the continental shelf survey office of HOD, who have been engaged in surveys and data reductions. He also thanks Drs. W. W. Sager and M. Nakanishi for their useful comments and suggestions. The English reviews by W. W. Sager significantly improved the manuscripts. GMT software v3.4 (Wesell and Smith, 1991) was used in the present study.

\section{References}

Beck, Jr., M. E., On the mechanism of crustal block rotations in the central Andes, Tectonophysics, 299, 75-92, 1998.

Bowin, C., R. S. Lu, C. Lee, and H. Schouten, Plate convergence and accretion in the Taiwan-Luzon region, Am. Assoc. Pet. Geol. Bull., 62, 1645-1672, 1978.

Deschamps, A. and S. Lallemand, The West Philippine Basin: An Eocene to early Oligocene back arc basin opened between two opposed subduction zones, J. Geophys. Res., 107(B12), 2322, doi:10.1029/2001JB001706, 2002.

Gee, J. and M. Nakanishi, Magnetic petrology and magnetic properties of western Pacific guyots: implications for seamount paleopoles, Proc. ODP Sci. Results, 144, 615-630, 1995.

Gee, J., H. Staudigel, L. Tauxe, and T. Pick, Magnetization of the La Palma seamount series: Implications for seamount paleopoles, J. Geophys. Res., 98, 11743-11767, 1993.

Grauch, V. J. S., A new variable-magnetization terrain correction method for aeromagnetic data, Geophysics, 52, 94-107, 1987.

Hall, R., Cenozoic geological and plate tectonic evolution of SE Asia and the SW Pacific, J. Asian Earth Sciences, 20, 353-431, 2002.

Hall, R., J. R. Ali, C. D. Anderson, and S. J. Baker, Origin and motion history of the Philippine Sea Plate, Tectonophysics, 251, 229-250, 1995.

Harrison, C. G. A., R. D. Jarrard, V. Vacquier, and L. Larson, Paleomagnetism of Cretaceous Pacific seamounts, Geophys. J. R. Astron. Soc., 42, 859-882, 1975.

Haston, R. B. and M. Fuller, Paleomagnetic data from the Philippine Sea plate and their tectonic significance, J. Geophys. Res., 96, 6073-6098,
1991.

Hide, T. W. C. and C.-S. Lee, Origin and evolution of the West Philippine Basin: A new interpretation. Tectonophysics, 102, 85-104, 1984.

Hildebrand, J. A. and R. L. Parker, Paleomagnetism of Cretaceous Pacific Seamounts Revisited, J. Geophys. Res., 92, 12,695-12,712, 1987.

Hildebrand, J. A. and H. Staudigel, Seamount magnetic polarity and Cretaceousvolcanism of the Pacific basin, Geology, 14,456-458, 1986.

Honza, E. and K. Fujioka, Formation of arcs and backarc basins inferred from the tectonic evolution of Southeast Asia since the Late Cretaceous, Tectonophysics, 384, 23-53, 2004.

Karig, D. E., Basin genesis in the Philippine Sea, Init. Rept. DSDP, 31, Washington (U.S. Govt. Printing Office), 857-880, 1975.

Kasuga, S., M. Hayashida, and collaborators in continental shelf surveys office, Publication of geomagnetic and gravity anomaly chart and characteristics of the magnetic anomalies in the southern waters of Japan, Hydrogr. Res. Rept., 30, 329-344, 1994 (in Japanese with English abstract).

Keating, B. and E. Herrero, Paleomagnetic studies of basalts and andesites from Deep Sea Drilling Project Leg 59, Init. Rept. DSDP, 58, Washington (U.S. Govt. Printing Office), 533-543, 1980.

Kinoshita, H., Paleomagnetism of sedimentcores from Deep Sea Drilling Project Leg 58, Philippine Sea, Init. Rept., DSDP, 58, Washington (U.S. Govt. Printing Office), 765-768, 1980.

Klein, G. de V. and K. Kobayashi, Geological summary of the north Philippine Sea, based on Deep Sea Drilling Project Leg58 result, Init. Rept. DSDP, 58, Washington (U.S. Govt. Printing Office), 951-962, 1980.

Kodama, K., B. Keating, and C. E. Helsley, Paleomagnetism of the Bonin island and its tectonic significance., Tectonophysics, 95, 25-42, 1983.

Koyama, M., S. M. Cisowski, and P. Pezard, Paleomagnetic evidence for northward drift and clockwise rotation of the Izu-Bonin forearc since the Early Oligocene., Proc. ODP. Sci. Results, 126, College Station, TX (Ocean Drilling Program), 1992.

Louden, K. E., Paleomagnetism of DSDP sediments, phase shifting of magnetic anomalies and rotations of the West Philippine Basin, J. Geophys. Res., 82, 2989-3002, 1977.

Matsuda, J., K. Sato, and S. Zashu, K-Ar ages and Sr isotope of rocks of manganese nodule nuclei from Amami Plateau, West Philippine Sea, Geol. Probl. Philipp. Sea, 99-101, 1975.

Matsuda, T., Collision tectonics of the Fossa Magna, Japan, J. Phys. Earth, 26, suppl., 409-421, 1978.

McNutt, M., Nonuniform magnetization of seamounts: A least squares approach, J. Geophys. Res., 91, 3686-3700, 1986.

Mrozowski, C. L., S. D. Lewis, and D. E. Hayes, Complexities in the tectonic evolution of the West Philippine Basin, Tectonophysics, 82, 1$24,1982$.

Ozima, M., I. Kaneoka, K. Saito, M. Honda, Y. Yanagisawa, and Y. Takigami, Summary of geochronological studies of submarine rocks from the western Pacific Ocean, in Geodynamics of the Western PacificIndonesian Region, edited by T. W. C. Hilde and S. Uyeda), American Geophysical Union Geodynamics Series, 11, pp. 137-142, 1983.

Parker, R. L., The rapid calculation of potential anomalies, Geophys. J. R. Astr. Soc., 31, 447-455, 1973.

Parker, R. L., A statistical theory of seamount magnetism, J. Geophys. Res., 93, 3105-3115, 1988.

Plouff, D., Gravity and magnetic field of polygonal prisms and applications to magnetic terrain corrections, Geophysics, 41, 727-741, 1976.

Randall, D., G. Taylor, and J. Grocott, Major crustal rotations in the Andean margin: Paleomagnetic results from the Coastal Cordillera of north Chile, J. Geophys. Res., 101, 15783-15798, 1996.

Richard, J. B., Potential Theory in Gravity and Magnetic Applications, Cambridge University Press, 1995.

Sager, W. W., Late Eocene and Maastrichtian paleomagnetic poles for the Pacific plate: Implications for the validity of seamount paleomagnetic data, Tectonophysics, 144, 301-314, 1987.

Sager, W. W. and M. S. Pringle, Mid-Cretaceous to Early Tertiary apparent polar wander path of the Pacific plate, J. Geophys. Res., 93, 11753$11711,1988$.

Seno, T. and S. Maruyama, Paleogeographic reconstruction and origin of the Philippine Sea., Tectonophysics, 102, 53-84, 1984.

Shin, T-C., Marine magnetic anomalies from the western Philippine Sea: implications for the evolution of marginal basins, in The Tectonic and Geologic Evolution of Southeast Asian Seas and Islands, Geophys. Monogr. Ser., vol. 23, edited by D. E. Hayes, pp. 49-75, AGU, Washington, D.C., 1980.

Talwani, M., Computation with the help of a digital computer of magnetic anomalies caused by bodies of arbitrary shape, Geophysics, 30, 797-817, 
1965.

Tokuyama, H., H. Kagami, and N. Nasu, Marine geology and subcrustal structure of the Shikoku Basin and the Daito Ridges region in the northern Philippine Sea, Bull. Of the Ocean Research Institute, University of Tokyo, 22, 1-169, 1986.

Ueda, Y., K. Kumagawa, and S. Kasuga. Geomagnetic anomalies of the seamounts near the Daito Ridge and their tectonic implication, Hydrogr. Res. Rept., 26, 241-260, 1990 (in Japanese with English abstract).

Ueda, Y., R. Kubota, and J. Segawa, Magneto-gravity response function and its application to the Daito Ridge, Geophysics, 67(1), 110-116, 2002.

Uyeda, S. and Z. Ben-Avraham, Origin and development of the Philippine Sea, Nature, 240, 176-178, 1972.

Uyeda, S. and R. McCabe, A possible mechanism of episodic spreading of the Philippine Sea, in Accretion Tectonics in the Circum-Pacific Regions, edited by M. Hashimoto and S. Uyeda, pp. 291-306, Terra Scientific Publishing Company (TERRAPUB), Tokyo, 1983.
Uyeda, S. and M. L. Richards, Magnetization of four Pacific seamounts near the Japanese Islands, Earthquake Res. Inst. Bull. Univ. Tokyo, 44, 179213, 1966.

Vacquier, V., A machine method for computing the magnitude and direction of magnetization of a uniformly magnetized body from its shape and a magnetic survey, in Benedum Earth Magnetism Symposium, edited by T. Nagata, pp. 123-137, University of Pittsburgh Press, Pittsburgh, Pa., 1962.

Vacquier, V. and S. Uyeda, Paleomagnetism of nine seamounts in the western Pacific and of three volcanoes in Japan, Bull. Earthq. Res. Inst., 45, 814-848, 1967.

Wessel, P. and W. H. F. Smith, Free software helps map and display data, EOS. Trans., AGU, 72, 441, 445-446, 1991.

Y. Ueda (e-mail: yoshio-ueda@kaiho.mlit.go.jp) 